\title{
PENERAPAN MODEL PEMBELAJARAN KOOPERATIF TIPE TEAM ACCELERATED INSTRUCTION (TAI) UNTUK MENINGKATKAN AKTIVITAS DAN HASIL BELAJAR MEKANIKA TEKNIK PADA SISWA KELAS X PROGRAM KEAHLIAN TEKNIK GAMBAR BANGUNAN SMK NEGERI 1 PERCUT SEI TUAN
}

\author{
Safrinanda Harahap ${ }^{1}$, Nono Sebayangg 2 \\ ${ }^{1}$ Alumni Program Studi Pendidikan Teknik Bangunan, Fakultas Teknik UNIMED \\ ${ }^{2}$ Dosen Pengajar Jurusan Pendidikan Teknik Bangunan, Fakultas Teknik UNIMED \\ (sby_nono@yahoo.co.id)
}

\begin{abstract}
ABSTRAK
Penelitian ini merupakan Penelitian Tindakan Kelas (PTK) bertujuan untuk menerapkan model pembelajaran Kooperatif Tipe TAI yang dapat meningkatkan aktivitas dan hasil belajar mata pelajaran Mekanika Teknik di Kelas X Program Keahlian Teknik Gambar Bangunan SMK Negeri 1 Percut Sei Tuan. Data penelitian diambil dari tes hasil belajar siswa, bentuk tes menggunakan soal multiple coice. Soal berjumlah 32 soal dengan empat option pilihan, dimana 16 soal untuk siklus pertama dan 16 soal untuk siklus kedua dan data aktivitas siswa diambil menggunakan Format lembar observasi siswa. Hasil penelitian menunjukkan aktivitas belajar siswa pada siklus I dengan hasil nilai rata-rata 77 dan prosentase kelulusan yaitu 72\% meningkat pada siklus II menjadi 89,60 dan Prosentase kelulusan yaitu 92\%. Hasil belajar siswa terjadi peningkatan, pada siklus I dengan hasil nilai rata-rata sebesar 72,75 dan prosentase kelulusan yaitu 72\% meningkat pada siklus II menjadi 85,25 dan Prosentase kelulusan yaitu 92\%. Berdasarkan hasil penelitian dapat disimpulkan bahwa dengan penerapan Model Pembelajaran Kooperatif Tipe TAI dapat meningkatkan aktivitas dan hasil belajar siswa pada Mata Pelajaran Mekanika Teknik Siswa Kelas X Program Keahlian Teknik Gambar Bangunan SMK Negeri 1 Percut Sei Tuan.
\end{abstract}

Kata kunci: Model Pembelajaran, TAI, Aktivitas, Hasil Belajar

\section{ABSTRACT}

This research is a Research Action class (PTK) aims to implement Cooperative learning model Type TAI that can increase the activity and results of the study subjects in Engineering Mechanical Engineering Program X-class Image of the building a CMS Land 1 Percut Sei Tuan. Research data taken from test results of student learning, the shape of the test using the reserved multiple coice. Reserved amounts to 32 questions with four option choices, where 16 reserved for the first cycle and 16 reserved for second cycle and data activity students are taken using the Format sheet of observation of students. The results showed student learning activities on cycle I with the results of the average value of 77 and graduation percentage i.e. $72 \%$ increase in cycle II becomes 89.60 and graduation Percentage that is $92 \%$. Improved student learning outcomes, in the cycle of I with the results of the average value of 72,75 and graduation percentage i.e. $72 \%$ increase in cycle II becomes 85,25 and graduation Percentage that is $92 \%$. Based on the results of the study it can be concluded that with the implementation of Cooperative Learning Model Type TAI can improve student learning outcomes and activities on subjects of Mechanical Engineering Students of class X Engineering Program Image of the building a CMS Land 1 Percut Sei Tuan.

Keywords: Model Of Learning, TAI, Activity, Learning Outcomes. 


\section{Safrinanda Harahap - Nono Sebayang}

\section{Pendahuluan}

SMK ini memiliki Program Kejuruan yaitu Teknik Otomotif, Teknik Permesinan, Teknik Bangunan, Teknik Audio-video, Teknik Listrik ,Teknik Komputer Jaringan dan Teknik Pendingin dan Tata Udara. Dari berbagai Program Kejuruan yang ada salah satu Program Studi Keahlian yang dimiliki SMK ini adalah Program Keahlian Teknik Gambar Bangunan, dimana mempersiapkan siswa agar dapat bersaing dan memenuhi kebutuhan lapangan kerja. Pada Program Keahlian Teknik Gambar Bangunan ada tiga jenis mata pelajaran yang digolongkan yakni: Mata Pelajaran Normatif, Adaptif, dan Produktif. Dari ketiga golongan mata pelajaran ini. Mata Pelajaran Produktif merupakan salah satu mata pelajaran yang sangat penting, karena siswa dituntut untuk mempunyai pengetahuan, keterampilan, dan kemampuan yang merupakan bekal bagi para siswa nantinya untuk dapat diterapkan dan dikembangkan pada dunia kerja. Salah satu mata pelajaran yang termasuk dalam mata pelajaran produktif tersebut adalah Mekanika Teknik. Mata pelajaran ini dianggap penting karena mekanika teknik dapat menghantarkan siswa kepada dasar memahami mata pelajaran produktif lainnya seperti : Mata pelajaran Struktur Beton, Struktur Baja, Struktur Kayu, dan lain- lain.

Berdasarkan data observasi awal Menunjukkan sebagian siswa masih mengalami kesulitan dalam memahami mata pelajaran Mekanika Teknik. Berdasarkan Kriteria Ketuntasan Munimum (KKM) yang ditetapkan sekolah adalah 75, Pada tahun pelajaran 2013/2014 Nilai Ulangan harian pertama terdapat $36 \%$ tidak tuntas dan $64 \%$ tuntas, pada Ulangan Harian kedua terdapat $40 \%$ Tidak tuntas dan $60 \%$ Tuntas, pada Ulangan Harian ketiga terdapat $44 \%$ tidak tuntas dan $56 \%$ tuntas. Selanjutnya tahun pelajaran 2014/2015 nilai ulangan harian pertama terdapat $44 \%$ tidak tuntas dan $56 \%$ tuntas, pada ulangan harian kedua $48 \%$ tidak tuntas dan $52 \%$ tuntas, pada ulangan harian ketiga 36\% tidak tuntas dan 64\% tuntas.

Dengan demikian kelas tersebut belum tuntas belajarnya. Menurut Arikunto (2012:62) menyatakan " Tingkat pencapaian untuk tes formatif adalah 75\%. Siswa yang belum mencapai Skor 75\% dari Skor yang diharapkan, diwajibkan menempuh kegiatan perbaikan
(Remedial Program) hingga siswa yang bersangkutan lulus dalam tes, yang artinya siswa tersebut telah mencapai skor $75 \%$ dari skor maksimal yang diharapkan". Berdasarkan Standart Ketuntasan Belajar Minimum (SKBM) yang ditetapkan Sekolah, maka Suatu kelas telah dikatakan mencapai kompetensi jika siswa pada kelas tersebut memperoleh skor 75 dan tuntas secara klasikal jika seluruh kelas $\geq 75 \%$ diantara siswanya sudah tuntas belajar. Dari uraian diatas, peneliti menganalisis terhadap permasalahan di kelas X Program Keahlian Teknik Gambar Bangunan SMK Negeri 1 Percut Sei Tuan, di perlukan adanya suatu inovasi terhadap kegiatan pembelajaran yang berlangsung dikelas, sebagai alternatif pemecahan masalah dikelas tersebut peneliti merencanakan untuk melakukan penelitian tindakan kelas dengan menggunakan model pembelajaran kooperatif tipe Team Accelerated Instruction (TAI).

Model pembelajaran kooperatif tipe TAI ini dikembangkan oleh Robert E.Slavin dalam karyanya Cooperative Learning: Teori, Riset,dan Praktik. Slavin (2005 : 187) memberikan penjelasan bahwa dasar pemikiran dibalik individualisasi pembelajaran adalah bahwa para siswa memasuki kelas dengan pengetahuan, kemampuan, dan motivasi yang sangat beragam Ketika guru menyampaikan sebuah pelajaran kepada bermacam - macam kelompok, basar kemungkinan ada sebagian siswa yang tidak memiliki syarat kemampuan untuk mempelajari pelajaran tersebut, dan akan gagal dari memperoleh manfaat dari metode tersebut. Siswa lainnya mungkin malah sudah tahu materi itu, atau bisa mempelajarinya dengan sangat cepat sehingga waktu mengajar yang dihabiskan bagi mereka hanya membuang waktu. Tipe ini mengkombinasikan keunggulan model pembelajaran kooperatif dan model pembelajaran individual, model pembelajaran ini dirancang untuk mengatasi kesulitan belajar siswa secara individual, oleh karena itu kegiatan pembelajarannya lebih banyak digunakan untuk pemecahan masalah Ciri khas pada model pembelajaran TAI ini adalah setiap siswa secara individual belajar model pembelajaran yang sudah dipersiapkan oleh guru. Hasil belajar individual di bawa ke kelompok-kelompok untuk didiskusikan dan saling dibahas oleh anggota kelompok, dan semua anggota 


\section{Penerapan Model Pembelajaran Kooperatif Tipe Team Acclerated Instruction (TAI) Untuk Meningkatkan Aktivitas dan Hasil Belajar Mekanika Teknik Pada Siswa Kelas X Program Keahlian Teknik Gambar Bangunan SMK Negeri 1 Percuit Sei Tuan}

kelompok bertanggung jawab atas keseluruhan jawaban sebagai tanggung jawab bersama.

Tujuan penelitian ini Untuk meningkatkan Aktivitas dan Hasil Belajar siswa pada mata pelajaran Mekanika Teknik Kompetensi Dasar Menghitung Tegangan Pada Struktur materi pokok Tegangan Lentur Pada Balok dan Tegangan Geser pada Balok di kelas X Program Keahlian Teknik Gambar Bangunan SMK Negeri 1 Percut sei Tuan tahun pelajaran 2014/2015 dengan menerapkan model pembelajaran kooperatif Tipe TAI.

Aktivitas belajar adalah segala sesuatu yang dilakukan oleh guru dan siswa dalam proses pembelajaran untuk memperoleh perubahan tingkah laku yang menyangkut pengetahuan, keterampilan dan sikap dalam rangka tercapainya tujuan pembelajaran Berdasarkan uraian di atas, yang diukur dalam penelitian ini adalah Visual activities, Oral activities, Motor activities, dan Mental activities. Dari Visual activities yang diukur adalah kegiatan memperhatikan pelajaran. Oral activities yang diukur adalah Kegiatan bertanya dan keaktifan dalam diskusi kelompok. Motor activities yang diukur adalah antusias siswa dalam melakukan percobaan mengerjakan soal secara individu serta menggali pengetahuan melalui pengalamannya sendiri. Mental activities yang diukur adalah kecakapan siswa dalam memberi jawaban terhadap soal yang diberikan oleh guru. Aktivitas ini diukur pada tahap observasi langsung dan dicatat pada lembar observasi. Hasil belajar adalah pencapaian yang didapatkan siswa dari proses pembelajaran yang diukur mengunakan tes, merupakan tolak ukur yang menentukan tingkat keberhasilan siswa dalam mengetahui suatu materi pelajaran. Hasil belajar merupakan indikator yang mengukur keberhasilan siswa dalam belajar. Siswa yang berhasil dalam belajar adalah yang dapat mencapai tujuan-tujuan dari pembelajaran. Hasil belajar yang dimaksud dalam penelitian ini adalah hasil mata pelajaran Mekanika Teknik pada siswa kelas X Program Keahlian Teknik Gambar Bangunan SMK Negeri 1 Percut Sei Tuan.

Dengan demikian, Penerapan Model Pembelajaran Kooperatif tipe TAI diharapkan mampu membawa siswa mencapai Aktivitas yang baik dengan ketercapaian target minimal mendapat nilai 85 mencapai $80 \%$ dari keseluruhan siswa dan Hasil belajar yang baik dengan ketercapaian Target minimal mendapat Nilai 80 mencapai $80 \%$ dari keseluruhan siswa diukur berdasarkan indikator ketuntasan belajar dengan rata rata komulatif kelas $\geq 80 \%$ Khusus mata pelajaran Mekanika Teknik pada Kompetensi Dasar Menghitung Tegangan pada Struktur Materi Pokok Tegangan Lentur Pada Balok dan Tegangan Geser pada Balok sehingga dapat menerapkannya dalam dunia kerja.

\section{Metodologi Penelitian}

Penelitian tindakan kelas ini dilaksanakan di SMK Negeri 1 Percut Sei Tuan pada siswa kelas X Program Keahlian Teknik Gambar Bangunan, yang beralamat di Jalan Kolam No.3 Medan Estate. Penelitian ini dilaksanakan pada semester genap T.P 2014/2015. Yang menjadi subjek dalam penelitian ini adalah siswa kelas $X$ Program Keahlian Teknik Gambar Bangunan SMK Negeri 1 Percut Sei Tuan T.P 2014/2015 yang berjumlah 25 siswa yang terdiri dari 18 siswa laki-laki dan 7 siswa perempuan.

Objek penelitian dalam penelitian tindakan kelas ini adalah meningkatkan Aktivitas dan hasil belajar siswa dengan menggunakan model pembelajaran Kooperatif Tipe TAI pada Mata Pelajaran Mekanika Teknik Kompetensi Dasar Menghitung Tegangan Pada Struktur materi pokok Tegangan Lentur Pada Balok dan Tegangan Geser pada Balok. Penelitian yang dilakukan merupakan penelitian tindakan kelas (PTK), yang terdiri dari dua siklus yaitu siklus I dan siklus II. Dimana setiap siklus dilakasanakan dalam dua kali pertemuan, apabila siklus II telah selesai dilaksanakan, namun hasil belajar belum juga meningkat maka dilanjutkan dengan siklus berikutnya sampai hasil belajar mengalami peningkatan. Adapun prosedur penelitian ini memiliki beberapa tahap, dimana setiap siklus terdiri dari: tahap perencanaan, tahap pelaksanaan, tahap pengamatan dan tahap refleksi.

Instrumen penelitian yang digunakan untuk mengukur hasil belajar siswa adalah bentuk tes menggunakan soal multiple coice. Soal berjumlah 32 soal dengan empat option pilihan, dimana 16 soal untuk siklus pertama dan 16 soal untuk 


\section{Safrinanda Harahap - Nono Sebayang}

siklus kedua. Sebelum digunakan, instrument tes telah dilakukan pengujian terlebih dahulu pada siswa kelas XI TGB SMKN1 Percut sei tuan pada 9 Mei 2015. Untuk menguji hipotesis dalam penelitian ini, digunakan teknik analisa statistik deskriptif yaitu mencari nilai rata-rata dan presentase keberhasilan belajar.

\section{Hasil dan Pembahasan}

Model pembelajaran kooperatif tipe TAI dapat meningkatkan aktivitas belajar siswa dalam menerima materi mata pelajaran menghitung Tegangan Pada Struktur pada siswa kelas $X$ program keahlian Teknik Gambar Bangunan SMK Negeri 1 Percut Sei Tuan. Hipotesis yang pertama mengatakan dapat meningkatkan aktivitas siswa dalam pembelajaran.

Dari pengamatan keaktifan siswa pada siklus I dengan 5 aspek yang diamati kepada 25 siswa, diperoleh nilai rata-rata pada pertemuan pertama sebesar 70,60 dan belum ada siswa yang mendapat capaian target yang mendapat nilai 85, pada pertemuan kedua diperoleh nilai rata-rata mencapai 77 dengan rata-rata komulatif kelas yang mendapat nilai 85 hanya 6 siswa dengan prosentase sebesar $24 \%$ hasil ini dapat dikatakan mengalami peningkatan dari pertemuan pertama namun belum mencapai target yaitu siswa ratarata komulatif kelas $\geq 80 \%$ mendapat nilai 85 maka dapat disimpulkan bahwa kelas dikatakan Cukup Aktif.

Aktivitas siswa dapat dikatakan masih rendah dengan rata-rata kategori cukup, sehingga dilanjutkan ke siklus II untuk meningkatkan aktivitas belajar siswa. Setelah dilakukan pengamatan pada siklus II terjadi peningkatan yang baik terhadap aktivitas belajar siswa, di mana dari 25 siswa diperoleh nilai ratarata pada pertemuan pertama sebesar 81,80 dengan komulatif kelas yang mendapat nilai 85 hanya 10 siswa dengan prosentase mencapai $44 \%$ hasil ini dapat dikatakan meningkat dari hasil sebelumnya, pada pertemuan kedua didapat nilai rata-rata sebesar 89,60 dengan rata-rata komulatif kelas yang mendapat nilai 85 mencapai 20 siswa dengan Prosentase mencapai $80 \%$ hasil ini sudah mencapai keberhasilan siswa rata-rata komulatif kelas $75 \%$ mendapat nilai 75 (ketuntasan Klasikal) maka dapat disimpulkan kelas sudah Aktif dan mengalami peningkatan pada siklus II. Sehingga dapat disimpulkan
Aktivitas belajar siswa Pada siklus II mengalami Peningkatan dari Siklus I.

Model pembelajaran kooperatif tipe TAI dapat meningkatkan hasil belajar Mekanika Teknik kompetensi dasar Menghitung Tegangan Pada Struktur pada siswa kelas $\mathrm{X}$ program keahlian Teknik Gambar Bangunan SMK Negeri 1 Percut Sei Tuan .Hipotesis kedua ini menyatakan dapat meningkatkan hasil belajar Mekanika Teknik. Dari pembahasan siklus I tentang hasil belajar Mekanika Teknik dengan melakukan Pretest dan Postest dari 25 siswa diketahui bahwa hasil Pretest hanya 9 siswa yang tuntas sesuai dengan standart Nilai KKM (75) selebihnya sebanyak 16 siswa dinyatakan tidak tuntas. Nilai rata-rata Pretest untuk seluruh siswa adalah 60,25 dengan prosentase kelulusan sebesar 36\%.

Setelah dilakukan proses pembelajaran selama dua pertemuan dengan penerapan model pembelajaran Kooperatif TAI hasilnya adalah pembelajaran meningkat, ini ditandai dengan peningkatan hasil postest yaitu sebanyak 18 siswa tuntas dan 7 siswa lagi dinyatakan tidak tuntas. Nilai rata-rata untuk postest meningkat menjadi 72,75 sedangkan prosentase kelulusan sebesar $72,00 \%$. Namun prosentase kelulusan ini masih di bawah dari nilai indikator keberhasilan siswa yaitu minimal nilai 75 dengan ketercapaian sekurang-kurangnya $75 \%$ mengacu pada kriteria ketuntasan belajar minimum yang diterapkan SMK Negeri 1 Percut Sei Tuan. Sesuai dengan data tersebut maka hasil belajar siswa dapat dikatakan belum berhasil, karena ketuntasan hasil belajar klasikal belum tercapai. Sehingga perlu dilakukan siklus II dengan menerapkan Model Pembelajaran Kooperatif Tipe TAI untuk dapat meningkatkan hasil belajar Mekanika Teknik.

Setelah dilakukan pengamatan pada siklus II maka persentase ketuntasan hasil belajar kelas mengalami peningkatan dan ketuntasan belajar secara klasikal sudah tercapai, dimana diketahui bahwa hasil pretest hanya 17 siswa yang tuntas sesuai dengan standart nilai KKM (75) selebihnya sebanyak 8 siswa dinyatakan tidak tuntas. Nilai rata-rata pretest untuk seluruh siswa adalah 74,25 sedangkan prosentase kelulusan hanya $68 \%$. Setelah dilakukan proses pembelajaran selama dua pertemuan dengan penerapan model pembelajaran Kooperatif TAI hasilnya adalah pembelajaran meningkat, ini ditandai dengan peningkatan hasil postest yaitu sebanyak 23 siswa 


\section{Penerapan Model Pembelajaran Kooperatif Tipe Team Acclerated Instruction (TAI) Untuk Meningkatkan Aktivitas dan Hasil Belajar Mekanika Teknik Pada Siswa Kelas X Program Keahlian Teknik Gambar Bangunan SMK Negeri 1 Percuit Sei Tuan}

tuntas dan 2 siswa tidak tuntas. Nilai rata-rata untuk postest meningkat menjadi 85,25 sedangkan prosentase kelulusan sebesar $92 \%$.

Berdasarkan kelima indikator observasi aktivitas sudah menunjukkan bahwa siswa sudah mulai terbiasa dengan konsep pembelajaran Kooperatif TAI. Aktivitas siswa dalam mengikuti proses pembelajaran sudah mencapai target. Hal ini dapat dilihat dari data hasil obeservasi aktivitas siswa pada siklus I pertemuan pertama nilai rata-rata aktivitas siswa 70,60 dan belum ada siswa yang mendapat capaian target yaitu mendapat nilai 85 dan pertemuan kedua nilai rata-rata aktivitas siswa mengalami peningkatan yaitu 77 dengan capaian target $24 \%$ atau 6 siswa yang mendapat nilai 85 . Pada siklus II mengalami peningkatan pada pertemuan pertama nilai rata-rata aktivitas siswa mencapai 81,80 dengan capaian target $44 \%$ atau 11 siswa yang mendapat nilai 85 dan pada pertemuan kedua meningkat menjadi 89,60 dengan capaian target $80 \%$ atau 20 siswa yang mendapat nilai 85 .

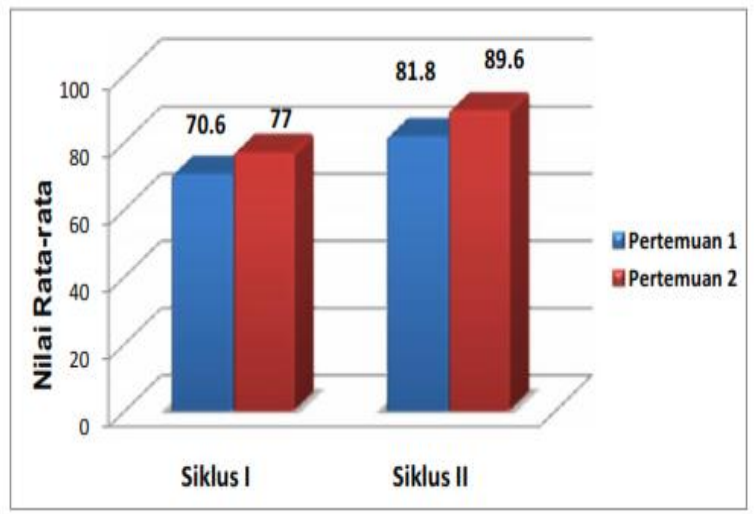

\section{Gambar 1 Grafik Perbandingan Aktivitas belajar Siswa Siklus I \& II}

Hasil belajar siswa dalam mengikuti proses pembelajaran sudah mencapai target. Hal ini dapat dilihat dari data hasil belajar siswa pada siklus I pertemuan pertama nilai rata-rata hasil belajar siswa 60,25 dan hanya 9 siswa yang mencapai KKM dengan prosentase 36\% dengan capaian target $4 \%$ atau 1 siswa yang mendapat nilai 80 dan pertemuan kedua nilai rata-rata hasil belajar siswa mengalami peningkatan yaitu 72,75 dan 18 siswa yang mencapai KKM dengan prosentase $72 \%$ dengan capaian target $40 \%$ atau 8 siswa yang mendapat nilai 80. Pada siklus II sedikit mengalami peningkatan pada pertemuan pertama nilai rata-rata hasil belajar siswa mencapai 74,25 dan 17 siswa yang mencapai KKM dengan prosentase $68 \%$ dengan capaian target $40 \%$ atau 8 siswa yang mendapat nilai 80 dan pada pertemuan kedua nilai rata-rata hasil belajar siswa mengalami peningkatan sebesar 85,25 dan 23 siswa yang mencapai KKM dengan prosentase $92 \%$ dengan capaian target $80 \%$ atau 20 siswa yang mendapat nilai minimal 80 .

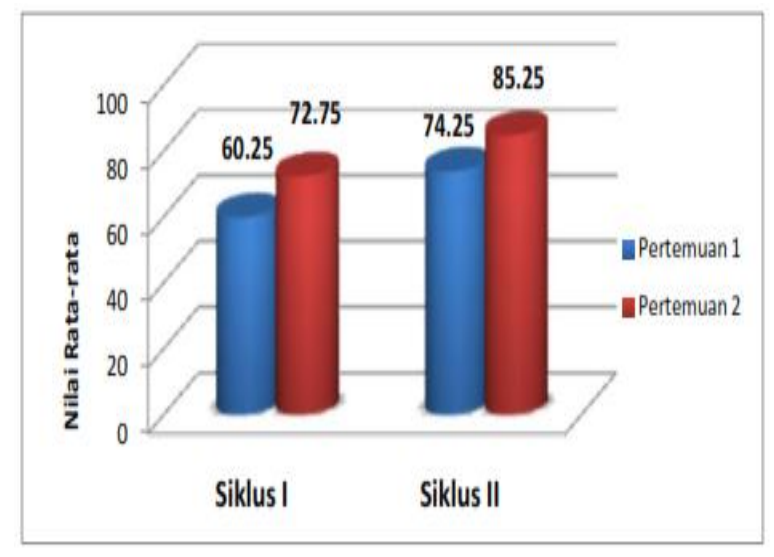

Gambar 2 Grafik Perbandingan Hasil belajar Siswa Siklus I \& II

\section{Kesimpulan dan Saran}

\subsection{Kesimpulan}

Berdasarkan hasil penelitian tindakan kelas dapat disimpulkan sebagai berikut:

a. Penerapan Model Pembelajaran Kooperatif Tipe TAI dapat meningkatkan aktivitas belajar siswa pada mata pelajaran Mekanika Teknik Siswa Kelas X Program Keahlian Teknik Gambar Bangunan SMK Negeri 1 Percut Sei Tuan. Hal ini dapat diketahui dengan nilai rata-rata hasil observasi aktivitas belajar siswa mengalami peningkatan, yaitu pada siklus I dengan nilai rata-rata komulatif kelas 77 dengan Prosentase kelulusan yaitu $72 \%$ meningkat menjadi 89,60 dengan Prosentase kelulusan $92 \%$ pada siklus II.

b. Penerapan Model Pembelajaran Kooperatif Tipe TAI dapat meningkatkan hasil belajar 


\section{Safrinanda Harahap - Nono Sebayang}

siswa pada mata pelajaran Mekanika Teknik Siswa Kelas X Program Keahlian Teknik Gambar Bangunan SMK Negeri 1 Percut Sei Tuan. Hal ini dapat diketahui dengan nilai rata-rata hasil belajar siswa mengalami peningkatan, yaitu pada siklus I nilai ratarata komulatif kelas 72,75 dengan Prosentase siswa tuntas belajar $72 \%$ menjadi 85,25 dengan prosentase siswa tuntas belajar $92 \%$ pada siklus II.

\subsection{Saran}

Setelah melihat hasil penelitian, pembahasan dan kesimpulan maka peneliti memberikan saran sebagai berikut :

a. Bagi Kepala SMK Negeri 1 Percut Sei Tuan Karena kegiatan ini sangat bermanfaat khususnya bagi sekolah, maka diharapkan mendukung pelaksanaan secara berkesinambungan sebagai referensi yang dapat digunakan oleh guru mata pelajaran lain.

\section{b. Bagi Guru}

Dalam kegiatan belajar mengajar guru diharapkan menjadikan model pembelajaran Kooperatif Tipe TAI sebagai suatu alternatif dalam mata pelajaran Mekanika Teknik untuk meningkatkan aktivitas dan hasil belajar siswa. Guru diharapkan mampu menjadi fasilitator yang terus-menerus membimbing siswa dalam membangun sendiri pengetahuan dalam menyelesaikan permasalahan materi pembelajaran.

\section{c. Bagi Siswa}

Model pembelajaran Kooperatif Tipe TAI mengkombinasikan keunggulan model pembelajaran kooperatif dan model pembelajaran individual, model pembelajaran ini dirancang untuk mengatasi kesulitan belajar siswa secara individual. Oleh karena itu kegiatan pembelajarannya lebih banyak digunakan untuk pemecahan masalah diharapkan siswa dapat menggali kemampuan individu yang dimiliki dan mengembangkan rasa kepercayaan diri. Dengan demikian siswa diharapkan memiliki keaktifan belajar yang tinggi di dalam menerima suatu materi pelajaran dengan konsep pembelajaran Kooperatif Tipe TAI, hal ini akan berdampak positif bagi hasil belajar siswa itu sendiri.

\section{Daftar Pustaka}

Abdurrahman, Mulyono. (2003). Pendidikan bagi anak berkesulitan belajar. Jakarta: Rineka Cipta.

Ariestadi, Dian. (2008). Teknik Struktur Bangunan Jilid 2 Untuk SMK oleh dian Ariestadi. Jakarta: Direktorat pembinaan Sekolah menengah Kejuruan, Direktorat manejemen pendidikan dasar dan menengah, Departemen pendidikan Nasional.

Arikunto, Suharsimi. (2010). Prosedur Penelitian Suatu Pendekatan Praktik. Jakarta: Rineka Cipta.

(2012). Dasar-

Dasar Evaluasi Pendidikan (Rev.ed). Jakarta: B umi Aksara.

Dimiyati dan Mudjono. (2006). Belajar dan Pembelajaran.Jakarta: Rineka Cipta.

Direktoral Pendidikan Menengah Kejuruan. (1979). Ilmu Gaya Teknik Sipil I. Jakarta : Departemen Pendidikan Dan Kebudayaan

Hamalik, Oemar. (2009). Proses Belajar Mengajar. Jakarta: Bumi Aksara.

Isnaini, Muhammad. (2011). "Penerapan Model Pembelajaran kooperatif Tipe Team Asisted Individualization (TAI) untuk menigkatkan Aktivitas dan Prestasi Belajar membaca dan mengidentifikasi komponen Elektronika siswa kelas X Teknik Audio Vidio SMK Swasta Bandung Kab. Deli serdang Tahun Ajaran 2010/2011". Skripsi Fakultas Teknik Universitas Negeri Medan. Medan

Kesumaningrum, Ratna (2007). Keefektifan model pemelajaran Tipe TAI melalui pemanfaatan LKS Terhadap Hasil Belajar Matematika Sub Pokok Bahasan Jajargenjang dan belah ketupat pada siswa kelas VII SMPN 11 Semarang T.A 2006/2007,. Skripsi Fmipa Universitas Negeri Semarang

Panjaitan, Daniel. (2011). “Penerapan Model Pembelajaran kooperatif Tipe Team Asissted Individualization (TAI) dalam Meningkatkan Hasil Belajar Dasar - dasar Kopetensi Kejuruan siswa kelas X Program Keahlian Teknik Gambar Bangunan SMK Negeri 1 Lubuk Pakam Tahun Ajaran 
2010/2011". Skripsi Fakultas Teknik Universitas Negeri Medan. Medan

Panjaitan, Thoga. (2014). "Penerapan Model Pembelajaran kooperatif Tipe Team Accelerated Instruction (TAI) untuk meningkatkan aktivitas dan hasil belajar ilmu statika dan tegangan pada kelas $X$ Bidang Keahlian Teknik Gambar Bangunan SMK N 2 Siatas Barita T.A 2013/2014". Skripsi Fakultas Teknik Universitas Negeri Medan. Medan

Sanjaya, Wina. (2014). Strategi Pembelajaran: Berorientasi Standar Proses

Pendidikan. Jakarta: Kencana Prenada Media Group.

Sardiman, A.M. (2011). Interaksi dan Motivasi Belaj ar Mengajar.Jakarta: Rajawali Pers.

Slameto. (2010). Belajar dan Faktor-Faktor yang Mempengaruhinya. Jakarta: Rineka Cipta

Slavin, Robert E. (2005). Cooperative Learning : Theory, Research, and Practice. Bandung: Nusa Media

Sudjana, Nana. (2004). Penilaian Hasil Proses Belajar Mengajar. Bandung: Remaja Rosdakarya

Sugiyono. (2005). Metode Penelitian Administrasi. Bandung: Alfabeta

Syamsudin, M.R. (2012). Statika Bangunan. [Onlin e]. Tersedia: (http://materies emka.blogspot.com/2012/01/kompetensi.h tml/) [diakses 10 Juni 2014].

Tricahyo, Gustus. (2012). "Keefektifan penggunaan Model Pembelajaran Kooperatif Tipe Team Assisted Individualization (TAI) dalam Meningkatkan Minat Belajar Dalam Pembelajaran PKM Kelas XI Mesin Si SMK Piri Sleman". Skripsi Fakultas Teknik Universitas Negeri Yogyakarta

Uno, B. Hamzah. (2011). Perencanaan Pembelajaran. Jakarta: Bumi Aksara.

Waltiyah, Eka. (2012). "Efektivitas Model Pembelajaran Kooperatif Tipe TAI (Team Asisted Individualization) dengan Learning Start With A Question Terhadap peran aktif dan Hasil belajar Matematika Siswa. Skripsi Fakultas Sains dan Teknologi UIN Sunan Kalijaga Yogyakarta. 